\title{
Underlying influences on Ben Marais (1909-1999)
}

P J Maritz ${ }^{1}$

Katholieke Universiteit Leuven

\section{ABSTRACT}

\section{Underlying influences on Ben Marais (1909-1999)}

This article considers various personal and academic influences on Ben Marais. The essence of these influences helped form his principles, was present in his early childhood, and is founded in his deep-rooted faith in God. Ben Marais was a child and a product of his times. The academic influences are approached through an analysis of a specific book that he claimed had influenced his thought, his MA dissertations and Ph.D-thesis. These formative influences helped determine his questioning the justification of policies in the NG Kerk.

\section{INTRODUCTION}

Ben Marais is known as the person who questioned and opposed the attempts of the Ned Herv or Geref Kerk (NG Kerk of Transvaal) ${ }^{2}$ to justify its controversial Mission Policy and the National Party's Apartheid policies $^{3}$. He was a well respected international ecumenical figure, a university chaplain, a professor of Church History, a radio personality and author of several popular and academic books, articles and book reviews.

The depression of the 1930s and the Du Plessis case were major events during his student years (1928-1936)4, the one social, and the other theological. After the Du Plessis case there was an aggressive reaction against critical thinking in the NG Kerk. How did the Du Plessis case influence Ben Marais' theological thinking? How did the "arm blanke

1 This article is an adapted chapter of a Ph.D.-thesis, titled: Ben Marais (19091999): the influences on, and heritage of a South African prophet during two periods of transformation, completed under the guidance of Prof. J W Hofmeyr of the Department of Church History of the University of Pretoria.

2 See Van der Watt (1987) for an overview of the history of the NG Kerk in Transvaal.

3 See Botha (1979), Brown (1992), and Maritz (2003).

4 See Die kerksaak tussen Prof J du Plessis en die Ned Geref Kerk in Suid Afrika (1931) for an overview of the tensions between Du Plessis and other members of the Stellenbosch Seminary. 
vraagstuk" influence him? What was the influence of Afrikaner pietism and evangelicalism (Scottish, German, Dutch and American) on his thought? Further questions that could be asked are: What did Ben Marais read? Who did he meet? What experiences influenced him? In this article, focus is restricted to early influences on Ben Marais. It is contended that these early influences were indicative of how he incorporated and dealt with conflicts and situations, and help to understand his persistent call not to base church policies on incorrect interpretations of Scripture.

\section{PERSONAL CONSIDERATIONS}

How did it come that a man coming from a pietistic, conservative background was able to detach himself from his peers' ideological and religious thinking - while remaining friendly with them - and proceed in the direction he did? Looking at his life chronologically, the gradual development of his thinking is detectable, as well as the presence of firm principles, many of which were imprinted during his youth. It is contended that the development of his thinking was evolutionary, supported by life experiences and measured against his principles - Christian and based on Scripture, while the essence of his personality, which remained constant, channelled the development of his thought.

\subsection{Youth}

Abraham Viljoen (Interview 1986) asked him about important influences from his youth. Viljoen mentioned the significance Psychology and the Behavioural Sciences place on development during the formative early years. Interestingly, Ben Marais indicated displeasure with the question, negating the importance of his early years. He mentioned his conservative, rural Afrikaner background - the thought world of the Afrikaner of the Eastern Cape - making it sound on the one hand, a world away from the world of academia and the contemporary issues of church, politics and race, and on the other, making it sound as if his early experiences were less influential than his studies and experiences at university, his tours abroad and into Africa, and the people he met and knew. He mentions that his later insights were not from childhood, but picked up along the way. This is referring to the first two decades of the twentieth century. However, his mother, Tant' Lizzie (Elizabeth Magdalena Botha) ${ }^{6}$, was

5 Poor white question.

6 Elizabeth is a family name, derived from the Murdocks. 
English orientated, and studied in Stellenbosch. Her father had been a gunsmith in the Cape, before selling his business and moving out to the frontier. The relations between the political parties (South African Party \& National Party) were tense. The Marais family - Afrikaners - were known to support the South African Party (Aucamp, Interview 17 September 2002). Thus, political disputes, conflict and tension resolution would have been primary concerns to the family.

In the Viljoen interview (1986) Ben Marais mentions a few influences. These influences are not explored in detail, only stated briefly. The first influence he mentions is his parents. He does not elaborate, neither does he mention his mother's death, nor the circumstances under which they had to leave the farm (Frisgewaagt). He mentions that he learned to love and appreciate all, which was rather general. Secondly, he mentions his uncles. The one uncle was a founder member of the National Party, another was a Manie Maritz rebel, a further two were Botha-Smuts supporters. He learned, within his broader family, how to deal with people who differ from each other. This would be an important consideration in his later ecumenical thinking.

Ben Marais' mother died shortly after the birth of Mara in 1917. She had been bleeding and the doctor was not capable of helping. The traumatic experience of his mother's death, and the subsequent breaking up of the family (Mara and Melvina went to live with family) must have left a mark on the then eight year old Ben. His father mourned his wife's death, and according to Pieter Marais, Ben Marais' nephew (Interview 20 September 2002), he never came out of the mourning, part of the reason why he sold the farm and moved to Middelburg. Charles, Ben Marais' brother, stated that he wished to become a doctor after experiencing the trauma caused by the incompetent doctor. He did so.

The circumstances surrounding, as well as under which Ben Marais' mother died, and the subsequent manner in which the Marais family dealt with it - most certainly governed by their religious convictions - would have affected the way Ben Marais would deal with loss, incompetence and trauma. On the one hand this experience, along with losing his elder brother, Pieter, the following year (1918), and his father's inability to cope with the death, would explain to a large degree why Ben Marais never spoke much about his youth. According to Alida Hattingh, a younger cousin of Ben Marais (Interview 17 September 2002), Ben Marais' father, 
Oom Willie, was a quiet person who did not have much to say. Apparently he drank aloe juice every Saturday, claiming that it was good for his health. Jean du Plessis, Ben Marais' nephew (Interview 04 October 2002), claimed that his grandfather never came out of mourning after his wife's death. Jean du Plessis told that his grandfather was a broken man in old age and had difficulty in recognising his daughter, Mara - Jean du Plessis' mother. The reference in Marais' Wit Huise van Herinneringe (1964c:28) to the nameless elder brother whom he accompanied to the veld, could in all probability have been Pieter. On the other, Ben Marais' instance on not provoking animosity could also be ascribed to these events. Thus, the tolerance that Ben Marais exhibited towards others could be attributed to the way in which he dealt with the traumas surrounding the family traumas between 1917 and 1918.

It is also told (C du Plessis Interview 12 September 2002) that Ben Marais was an active and inquisitive child. The story is told that he once, at the age of two, poured sand into the butter machine. Apart from this causing much distress and fury, the way in which he was punished would also have contributed to the manner in which he acted towards those who wronged him. The self discipline taught in the Marais' household, the openness between the siblings and the religiously determined disciplining would have contributed towards and accentuated the manner in which Ben Marais dealt with disputes: he talked about it. This fact is exhibited in Ben Marais' writing to the secretaries of the World Council of Churches, voicing his concerns at the synods, and is substantiated by the fact that the Marais family is known for being verbal about injustices and involving themselves in causes they deem worthy ( $\mathrm{J}$ du Plessis Interview 04 October 2002).

Many of the personality traits exhibited in Ben Marais were also present in his siblings and other close family, making it most probable that a common orientation would have contributed towards his attitudes. Ben Marais was thus not a unique individual, but rather a person who acted according to the behavioural patterns imprinted upon him during his youth.

Education played an important role in the Marais' household. Before taking over the responsibility of caring for the younger children after her mother's death, Johanna had studied to become a teacher. Ben Marais' mother had received tertiary education in Stellenbosch, and his father was involved in the farm school on Mooihoek. One of the reasons why the 
family moved to Middelburg in 1922 was due to the existence of the high school there. In the early 1920s it was the largest school in the Cape Province.

English was the language of the British government. Proponents of Afrikaans were aspiring for its official recognition and for its use as the medium of instruction in schools. Ben Marais was part of one of the first groups to receive tuition in Afrikaans. The Marais family was not antiEnglish, as were many Afrikaners in the post Anglo-Boer War era in the Middelburg district. The Afrikaner and English farmers had got on very well before the Anglo-Boer war, and many had inter-married. In Middelburg, though, a large Town Guard, stationed at Grootfontein had to be deployed after the war to maintain the peace.

There were religious revivals in Middelburg during the 1920s. These could have contributed towards Ben Marais becoming aware of his calling to become a minister. He does not mention these revivals anywhere, but the coincidence is very big.

\subsection{Student Years}

The leadership skills of Ben Marais were well groomed at Stellenbosch. While race was not a controversial issue during the late 1920s and early 1930s, he developed his skills as a journalist and spokesperson, as well as a historical-philosophical line of inquiry. In his chairmanship of the men's residence, Wilgenhof, and of the Student Council, he had developed into a strong leader. The Du Plessis case took place during his student years, and in his experience of this, he developed an aptness at discerning the various issues, and striving to understand the underlying principles, and to measure these against the religious principles as he determined them from Scripture (Meiring 1979:79).

\section{STUDIES}

Ben Marais' preparation did not begin when he went to Stellenbosch; according to C Du Plessis (Interview 12 September 2002) he used to learn the church's hymns in the house's loft. Interestingly, Ben Marais was not known to be able to hold a tune (P A Marais Interview 17 December 2002), but he often hummed and whistled hymns associated with the topics of the sermons he was preparing. He had a photographic memory ( $\mathrm{P}$ A Marais 20 September 2002), which would have enabled him to recall facts and information with ease. Besides this, from his experiences and 
successes as a journalist at university, it is obvious that he was multitalented, having the talent also to express his thoughts, and did not need to be taught to do so.

Distinction is made between two types of literary study Ben Marais undertook. The first illustrates the manner in which a book influenced his thought, and the second illustrates how his formal studies contributed towards his forming as a Church Historian and his formidable pronouncements in the church.

\subsection{Informal Studies}

The book by B B Keet, Whither South Africa? appeared in January 1956. Ben Marais was able to identify with the book, and drew much encouragement from it. Some years earlier, when he was a student, he read E Shillito's Nationalism: Man's Other Religion.

\subsubsection{Nationalism: Man's Other Religion (1933): E Shillito}

In the front of his copy, which he first read in 1933, Ben Marais had written: "Gaan my nasionalisme my godsdiens bepaal, of gaan my godsdiens my nasionalisme bepaal"?

Ben Marais was a student (1928-1936) during the post "Great War" period (1914-1918). South Africa was not as directly involved in the war as were the European sovereign states. The volunteers from the regions where Ben Marais grew up, found themselves fighting in German South West Africa, either for or against the Boer general, Manie Maritz. One of the questions being asked within the general state of nationalistic disillusionment, more abroad than in South Africa, was the question of the relation between nationalism and religion. Ben Marais read one such book - written by an American - that was determined to make sense out of the general state of disillusionment by trying to establish patterns in history, and tracing the buildup to the catastrophic war in 1914. It claims to "provide a serious call to the reader to consider afresh this alternative way offered to the spirit of man along with the perils to which it leads" (Shillito 1933:Preface). This alternative way was to treat nationalism as a religion. Ben Marais was able to apply what he read to the South African situation, and thus the book profoundly influenced his thought, so that he was able to

7 "Will my nationalism determine my religion or will my religion determine my nationalism". 
distinguish between matters of religion and matters of nationalism and patriotism. The book also promoted his sense for ecumenism (Viljoen Interview, 1986).

Nationalism: Man's Other Religion (1933) consists of six chapters, each with accompanying illustrative sketches, of which it is suggested, "are meant to gather up the main themes of the book in a historic scene or myth". The contents of the book reflect greatly on Ben Marais' own forbearing on the state of affairs in South Africa, namely on the relations between church, state and culture, and the relations between the various race groups. It is thus necessary to dwell briefly on its contents.

The first chapter, "Man's other religion" considers the essential theoretical framework for considering nationalism in the same light as religion. The author's evangelical orientation is determined indirectly through the allusions made, the structure given to reality and the perceptions on history and relation to Scriptures. The accompanying sketch gives a brief history of Karl Marx. Shillito rejects communism as a determined alternative to Christianity and Nationalism (1933:105). This book claims that "the problems of communism and nationalism may be treated as political; but the strength of communism and nationalism does not lie in their political theories, but in their powers to fill the place of a religion" (1933:2). Communism is understood to be a "godless church, filled with a religious passion, possessed by a desire to banish the God, whom man had made out of his dreams" (1933:2). Nationalism is discussed as an alternative to Christianity. The book's influence on Ben Marais is clearly visible when he considers the church as an alternative to nationalism (The two faces of Africa).

By religion Shillito means "the reference of all things human to one master - interest which has been found by most religious people in the mind and will of God; but there can be objects of worship and devotion other than a personal God" (1933:1). Shillito discusses how, in earlier times within the tribal system, there was a close relation between the tribe's defence and its religion, and that as time went on, the religious aspects were eroded and the tribal - nationalistic - interests became revered, resulting in "many altars being dedicated to Patria, and among the worshipers are men of every creed. Thus, the communality of nationalism across creeds, races, and across time is established. This would make it possible for Ben Marais to consider race problems in the Americas, and 
to draw parallels and differences with the situation in South Africa, because he first tried to establish communality and differences.

An important question is: How would Ben Marais have read the book, against his pietistic, evangelical Afrikaner background, on the one hand, and his schooling in Greek Philosophy on the other? It is my belief that he would have read it analytically, but not critically. The reason for this is the fact that the language would have been quite familiar to him. For example, Shillito's call to repent (1933:4), which I experience as manipulative reasons: "Nationalism is another religion which offers itself to the hungry soul of man. In face of it the church must repent. No serious call can ever be made which does not begin with the demand that men must everywhere and always adjust their minds to reality, and this is an essential part of what is meant by repentance".

Reality is perceived from a 1930s middle class American point of view. As substantiation to his argument on "adjusting" in the face of changing reality, Shillito (1933:5), refers to Alaric when he attacked Rome in $410 \mathrm{CE}$, and "when the men were blind" when he stood at the gates. Shillito claims that the Romans should have adapted to the new reality, then they would have been saved. Furthermore, the French nobles "living a life of wit and elegance till the eve of Revolution" (1933:5) are referred to along with the "Russian aristocracy [who] never dreamed of being driven out into exile" (1933:5). On the one hand, Ben Marais' noble French heritage $^{8}$ would have inspired him to associate with the reasoning; furthermore, to perceive the patterns in history, along with the reference to the ill fate of the Russian aristocracy, at the hand of the feared communism. The book could be argued to be propagandistic.

Though, if read analytically, it is possible to perceive the dangers of nationalism in the South African society. The moral drawn by Shillito (1933:6), states clearly "the moral of history is plain, if others were blind to the signs of the times, we too may be blind". In this assertion there may also be truth for the current reader, not only for Ben Marais. This relates to Ben Marais as a prophet, though, not self perceived, but made applicable to him (1933:6): "Those who prophesy disaster, if something is not done, are called Cassandras or Jeremiahs. But Cassandra was right, Troy did fall. And Jeremiah was right, Jerusalem was captured...". Within this realism,

8 His forefather, Charles Marais, a Huguenot, was a French nobleman. 
the "real world" according to Shillito (1933:6), there is an altar, and on the altar is an inscription: "to Fatherland". Also, the church is silent (1933:7): it has either nothing to say, or it is afraid to speak. Ben Marais was one person who decided that he would not be afraid to speak. Also, he had much to say. He would have found the words, "The world is listening for any voice that can speak with authority" (1933:7) inspiring. Though, Hitler also spoke with authority, some years later, and was able to capture the psyche of a nation.

Simultaneously, and related, Shillito indicates a sensitivity to direct application of Scripture on $20^{\text {th }}$ century society (1933:11). This hermeneutic principle would have made Ben Marais weary also of Scriptural justifications of societal practices and norms. Thus: "The church cannot give the precise witness which the faithful servants of God gave in Asia Minor in the days when the Apocalypse was written; it can but adjust its thought and action to the spiritual situation which it inherits in the $20^{\text {th }}$ century" (1933:11).

The realism for the church lies in the fact that "the Kingdom of God is at hand" (1933:8). Thus implicating that within biblical imagery, nationalism is imbedded, while also needing to be reinterpreted for the reality of the $20^{\text {th }}$ century. The difference between nationalism and realism is considered by Shillito in very simplistic terms in the basic model: "Nationalism has to do with the outward and temporal affairs; Religion is inward and spiritual" (1933:9). Shillito then determines that the church has been at once a divine and a human society, that it fulfils an eternal purpose, but in time. This substantiates Ben Marais seeking to resolve the nationalistic differences within the structures of the church (The two faces of Africa).

While the book frequently refers to nationalism, it gives different meanings to it. One of the more important references places it in a historical context, namely the disillusionment with nationalism experienced after the Great War (1933:13). Shillito refers to nationalism as "the mind and action of those who believe in a sovereign state above which there can be no higher power" (1933:13). Shillito draws the history of sovereign states in Europe over four centuries, though also being weary to indicate it as a human phenomenon affecting all of mankind. To this effect he quotes Gokhale, an Indian nationalist, who would have expressed the creed of nationalism: "Love of country must so fill the heart that all else shall ap- 
pear of little moment by its side". This would have horrified Ben Marais, who insisted that he was a Christian before he was an Afrikaner (Viljoen Interview, 1986).

A look at nationalism from a different angle sees it being as compared to patriotism (1933:16). In this comparison Shillito finds patriotism to be contrary to nationalism. The book reasons, "not to condemn, but to save patriotism the church has come. Nationalism unchecked will make an end of the nation" (1933:17).

On a different point, but also akin to the times, Shillito discusses Islam, though he sees it not as a threat (1933:15). Ben Marais, who - as expressed in correspondence with the World Council of Churches - was well aware of Islam, considered the religion a daunting threat over the church. Shillito is very naïve in calling Islam "a faith for the man in the desert" (1933:14), and negates it by considering it an "ancient protest against superstition" (1933:14). One could as easily classify Christianity as such. Much of the tension between Christianity and Islam can be detected in the book's attitude towards Islam, where cultural bias most certainly plays a role, even as Shillito sweepingly claims that Islam, "in its positive teachings, it is out of touch with modern knowledge" (1933:14). This knowledge is culturally determined, and modern is considered more affluent than traditional, and he appears to claim to have access to this knowledge. This comes across as quite arrogant. However, a person reading the book, and sympathising in a similar cause might not necessarily find alarming fault with such an attitude. Shillito thus emphasises internal threats far more than external.

At the end of chapter 1 a short historic sketch is given of Karl Marx, emphasising strongly his work in the library. On the one hand, Karl Marx was confronting the reality of his day, the poverty, abuse and maltreatment experienced and the silence of the church. On the other, Shillito makes Karl Marx irrelevant through the one-sided treatment of his history, thus also neutralising effectively the threat that communism supposedly held. He concludes on Karl Marx (1933:25): "Still the same stream enters the British Museum. It is possible that among the living readers there is one whose studies will be among the forces which are for the rising and falling of the nations." Ben Marais would not have been so arrogant as to consider that his writings would determine the rise and fall of a nation. Rather, in retrospect, it must be claimed that his teachings and understanding of 
reality, as also influenced by this book, influenced later generations to effectively take steps to change negative policies within the church.

The second chapter, "Where the streams meet", takes a closer look at the contemporary world in the context of the Great War. The two streams distinguished by Shillito are, firstly, nature, and secondly, man's spirit (1933:27). This distinction is most certainly not as profound in the $21^{\text {st }}$ century as it was during the 1930s. Drawing from the theory considered in chapter 1, Shillito claims that man must adjust to the new reality as it has come to be known (1933:27). Thus, repentance is an adjustment to the new facts (1933:27).

Shillito considers the Great War to be an "explosion to which four centuries of nationalism in Europe led" (1933:28). Apart from establishing an European orientation to World War I and viewing the war as a conflict of established nationalisms, he tries to understand the war within a broader historic context, as Ben Marais also tries to understand the race problems in South Africa against a broader historic framework.

This book is more idealistic than practical, and it comes from a middle-class American perspective, but the book's propagation for moving from nationalism to internationalism (1933:28-29) reiterates the move from a focus on individual nationalisms to the interaction between nations, which, interestingly, corresponds to the rising emphasis being placed on ecumenism. One post war movement, identified in the book, is akin to such a movement away from nationalism towards internationalism, as seen in the formation of the League of Nations, the Pact of Paris, and different meetings and conferences on science, medicine, commerce and finance. This movement implies a dogmatic denial of traditional groupings (1933:29-30). A second post war movement (1933:30) is reflected in the outbursts of nationalism and concerns "the revival of the idea of the sovereign state" (1933:30). The reason for this, according to the argument, is that "in times of uncertainty man turns inwards and finds sanctuary in the narrower limits of the own country" (1933:30). This predicament could have been an encouragement for Ben Marais to seek dialogue and establish relations with others, and to consider the arguments of others (S Marais Interview 2000).

In chapter 3 the theme of the altar is referred to once more, "The revival of an ancient altar". The altar, which is dedicated to Patria, Fatherland, is an "altar that has been revived and rededicated, but it is the 
same altar before which man has bowed in many ages and in many lands" (1933:51). Shillito reasons that in early history the name of the god and the name of the tribe were linked. Devotion to Patria came to have a sacred value, and "when the gods vanish in the mists, the nation remains to take over the entire loyalty, and to fill the empty place in the heart of the people" (1933:51).

In the build-up of the argument, examples of nationalism from Scripture and from the Highlands of Scotland are presented (1933:52-69), the history of Israel in nationalistic terms, and finally it suggests that the church is the new Israel in nationalistic terms. The church is seen as "a spiritual race, an elect people, its members went out to do what Israel, as a dedicated people, might have done" (1933:67). A critical question is asked in this regard, "Is the nation to live for itself or give itself to the Kingdom of God?" (1933:68). This is then drawn to the books contention that The City of God of St Augustine is seen as the place in which all the nations bring their honours (1933:68). Thus, the future of nationalism is considered in an eschatological framework, whereas St Augustine's City of God is seen to be akin to an international meeting place of different nations. Shillito points out that Augustine developed the City of God to stand against the City of Earth (1933:69), which is at once temporal, decadent and on which one cannot trust. Thus, it appears that Shillito supports the idea that St Augustine wrote The City of God in his bereavement and while experiencing disillusionment at Alaric's invasion of Rome.

In chapter 4 the book considers the development of the nationalistically orientated sovereign states of Europe. This is accomplished in "The Shadow of Machiavelli". Niccolo Machiavelli, a Florentine who wrote in Italy in the $16^{\text {th }}$ century, is considered to have influenced European political thought. The book in question is Concerning Principalities (1532), also referred to as The Prince. The book, which was not intended for publication, interprets changes in the spirit of man which were to be operative for four centuries in Europe (1933:81). The Prince, which served as a series of instructions to the "most magnificent Lorenzo de Medici" (1933:94), is important for its underlying theory of state. The ordering of the state is described with the assumption that this is the issue with which practical men must deal. There is thus little room for the spiritual guidance of the church in public life. Shillito (1933) thus sees a general attitude towards the nationstate logically expressed in Machiavelli, and believes that this 
attitude has been the assumption of civilised communities for centuries (1933:81).

Shillito presents an interesting periodisation model (1933:80). In this model St Augustine is seen as an important moment in European political thought with his development of the idea of the eschatological City of God. The first period, then, leads up to the $16^{\text {th }}$ century, in which Martin Luther and Machiavelli respectively signify the Reformation and the Renaissance. These two events, the reformation and the renaissance are considered parallel, and together form the onset of the second phase of the development of the sovereign states in Europe. The second phase lasted until after the Great War, from whence the third phase proceeded. Thus, the relations between church and state are pertinent to the development of nationalism in Europe. Shillito offers several examples (1933:84-104), such as Hildebrand's sentence over Henry in 1076 (1933:84). The reformation is given an interesting political interpretation.

A further example that has a parallel in South African history, and thus would have been interesting to Ben Marais, concerns Cardinal Richelieu (1933:97). The Cardinal encouraged Protestant powers to fight against a Catholic State which posed a political danger to France. Nationalism thus prevailed over religion. In the annals of South African history, in the late $18^{\text {th }}$ century, when the Cape was gouverned by the Dutch East Indian Company, Roman Catholics were not allowed to celebrate Mass, and were generally not welcomed by the Protestants. Many of these sailors were French. Several years later, when the Cape settlers felt that the Protestant English posed a threat to their safety, the Catholic French sailors were welcomed in the Cape (Hofmeyr \& Pillay 1994:10) Thus, in times of distress nationalistic concerns predominated over religious differences. As Cardinal Richelieu's attitude led to the development of the idea of sovereign states - in which no allegiance was owed to any higher power (1933: 97), so, in contrast, the religious powers continued to be influential in South African society well into the $20^{\text {th }}$ century. Within the parallel there is a difference, indicating how difficult it is to draw direct lines between European and South African societies. One reason for the dissociation was the influence of the Scottish evangelical orientated ministers who served in the Cape NG Kerk during the $19^{\text {th }}$ century, and the interpretation of the Scriptural passage - Romans chapter 13. 
The third chapter concludes with the consideration of three main alternatives for the spirit of man. While being rather simplistic, regarding communism as the worship of the proletariat and nationalism as the worship of the Sovereign State, and Christianity being the other alternative, Shillito's assertion that "man has always been a worshiper" is quite useful (1933:105). It would have promoted the idea of remaining within the church and challenging the status quo from within the church and refusing to become politically active in the thought and actions of Ben Marais.

The historic sketch at the end of chapter 3, "Machiavelli writes The Prince", is very informative, apart from substantiating the book's premises on the relation between religion and nationalism. Shillito presents influential leaders that read the book (in the library - akin to Karl Marx) (1933:106). From The Prince, according to Shillito (1933:110), it is possible to discern how the lines of renaissance, religion and nationalism interplayed. Leaders, such as Richelieu, Napoleon and Bismark would have read in The Prince (1933:110): "Clear intelligence backed by unsparing will, unflinched energy, remorseless vigour, the brain to plan and the hand to strive - here is the salvation of states." Religion is seen to be good - but should not be allowed to dominate, while political language is shrouded in religious terms. The sovereign states are seen to be each an end in itself - each the sole guide of its own life; "and in statesmanship everything would be justifiable which was needed to preserve or further the state" (1933:110).

The last two chapters, "Education for life in the nation", and "A large upper room furnished", appear to be more dogmatic, disclosing the author's unprecedented sentiments on the subject. Shillito, though, approaches the subject through a referral to the Chinese national Sun-YatSen, thus Christianising global trends. The observations in these chapters would have had particular significance to Ben Marais' thoughts on ecumenism.

In chapter 5, Sun-Yat-Sen is quoted, where it is claimed that a society must first be national before it can be a society internationally (1933: 113). The state of being "international" can be achieved by two means: the process of promoting international order, thus fellowship between existing nationalities; or the process of ending all former groupings, the process of denationalisation (1933:114). Thus the two 
alternatives presented are anarchy and internationalism, where Education, through History (manipulated) is shown to work in the model of love and hate - hatred for the other and love for the own (1933:120). Shillito wishes to promote positive nationalism - patriotism (1933:21), and concludes the chapter with an inspired observation (1933:136): "The key to the future is in the satchel of the school boy".

The final chapter, "A large upper room furnished", reasons that the church faces a new task in each generation, where no exact parallel can be found in the past (1933:147). In the analysis of the post Great War problem, Shillito tries to indicate the duty of the church. Counsel is offered to the church, which covers positive and negative assertions (1933:148).

Three positive points of counsel are presented, namely, 1) that the church must assert firmly its catholicity, in the sense of being international; 2) that a new emphasis needs to be placed on the application of Christian faith (mention is made of the meeting at Stockholm 1925 and the derived English orientated "Life and Work" and European orientated "Ecumenical Conferences", as well as a renewed missionary enterprise); 3 ) that the church should be a living witness (related to the idea that man has more in common than what divides). The negatively orientated counsel suggests that the church should refuse to be chaplain to the modern state (1933:148). The disillusionment following the $1^{\text {st }}$ World War is very apparent. A mixed society, like the United States of America, of which the author is a member, would have experienced the relations between churches and states in a different light to their allies and opponents across the Atlantic.

The counsel is followed by several excursions on what the author perceives what the church should and should not be, should and should not do (1933:151-166). The primary focus is to seek peace in the world and reunion of the church. This assertion is rather ironically expressed in a publication of the early 1930s, considering the build up of national powers in Europe, which would lead to the $2^{\text {nd }}$ World War.

The final excursion in the book, following chapter 6, "The upper room", contains a strong reference to where the Last Supper was eaten. The vision is explored where different people from different nations share a common meal. This vision is contrary to the NG Kerk's assertion and practice of separate Eucharist, church services and churches! It would have 
implored Ben Marais to consider carefully the church's doctrines on unity and community and the justification of its controversial doctrines.

A discussion of his masters and doctoral studies indicates, firstly how his interests and thoughts developed, and secondly how his formal studies influenced his thoughts. It is also evident from an extended consideration of a book that he claimed (Viljoen, Interview 1986) had greatly influenced him, how his informal studies also influenced his thoughts. Ben Marais was not only active in the church, though, he also had interests in sports bodies and in student affairs. The question is, to what extent his involvement in these activities influenced his thoughts and pronouncements?

\subsection{Formal Studies}

Ben Marais' undergraduate studies are not discussed as a separate category. Rather, focus falls on his postgraduate studies, where influences on him and the development of his thoughts are more clearly discernible.

\subsubsection{M.A. in Afrikaans, Stellenbosch, 1932}

Ben Marais' MA dissertation in Afrikaans, completed in September 1932, is probably the most informative about the way he thought and about his academic and creative development. The dissertation reveals artistry with words and concepts and clarity of thought. The ability to convey difficult ideas in a simplified form, very evident in his later writing, is very fresh and evident in this dissertation.

The title ${ }^{9}$ indicates that the study Ben Marais undertook was about the literary styles introduced by the Dutchman Arthur van Schendel who is identified with the Romanticism of the $19^{\text {th }}$ century. The argument is well presented and poetically articulated through descriptive language and images.

He begins his argument on renewal with a metaphor in which he compares the renewal in literature to the rejuvenation in the four seasons $(1932: \mathrm{i})^{10}$ :

9 Die Romanticus Arthur van Schendel as Stylvernuwer.

10 "Die lente kom uit die winter en die herfs ... Dis 'n nuwe lente! Maar nuut is dit alleen omdat dit uit ' $\mathrm{n}$ ander jaargety gebore is. As die winter ook lentebotsels gehad het, as die velde ook groen was en die geur van blomme in die wit maanskyn 
"The spring comes forth from the winter and the autumn ... 'It is a new spring!' But it is only new because it is born from another season. If the winter also had spring buds, if the veld were also green and the aroma of flowers in the white moonlight dwindled through the valley, then spring would not have been new, because an own beauty and an own gleam it would not have had".

In a further metaphor employed by Ben Marais (1932:iv) he describes literary art - new style forms - against "the background and broad rivers from which this art stream flows clearly into sight"11. Ben Marais' discussion of the renewal of a literary school and of style and art is compared to the flowing of a river, emphasising his orientation to literary history and to the relation between his argument and his subject on the one hand, and the relation between the different fashions in literary schools on the other. He then states (1932:iv) that he will be writing about Romanticism in general and about style in more detail.

In the subsequent chapters of the dissertation, Ben Marais discusses Romanticism in literature, Dutch Romanticism and their development, style in general, Arthur van Schendel's contribution, his collections of stories, and travel stories. He concludes with a chapter on the new work of Van Schendel.

Though the study is in Dutch and Afrikaans literature, Ben Marais' methodology, arguments and conclusions reveal much about his own personality, style and academic development and perception on reality. $\mathrm{He}$ distinguishes art into two categories (1932:1): Realism - which is are determined by the deed, reality and the present; and Romanticism - which is built on the dream. He elaborates on Romanticism, calling it the art that reaches in the distance, a flight to the world of dreams, of thought, a search for foreign things, for the supernatural, for the mysterious. All which is compared to the youth. Romanticism is thus defined as (1932:2): "Die oneindigheidsgeroep wat die eindige van sy moeisame knelters losmaak". On reading the dissertation it becomes apparent that Ben Marais could be considered a Romanticist. This is especially true considering his remark that Romantics are often the great lonely people in life. His years of

deur die vlakte gedwaal het, sou die lente nie nuut gewees het nie, want ' $n$ eie skoonheid en 'n eie glans sou dit nie gehad het nie".

11 “... en breë riviere waaruit hierdie kunsstroom kom helder in die gesig te kry nie". 
isolation and his intense experience of loneliness during this period comes to mind. It would thus appear that Ben Marais was prepared for such a life. It is not sure to what extent he could have drawn on past experiences from his youth - these years are shrouded in mystery. As a Romanticist, though, Ben Marais would not have considered himself withdrawn, since he states $(1932: 4)^{12}$ : "The true Romanticist does not stand outside of reality and is not eager to avoid reality in his art, does not stand outside and lose from real life." A further surprising revelation in the dissertation is found in his commentary on Bosboom-Toussaint and van Lennep concerning the relationship between author and work, an aspect for which Ben Marais is well known. In his commentary he accuses these historical novelists of $(1932: 8)^{13}$ : “... little emotion and little warmth of the internal. Theirs were the general - though sometimes refined - but still almost colourless historical documents - deep personal accents were absent." The personal touch in especially Ben Marais' devotional writing, and also evident in his two books The two faces of Africa and Colour: unsolved problem of the West, could be traced to his grooming as a student of Dutch Romanticism. Style, also, is evidently a personal matter, as Ben Marais remarks $(1932: 25)^{14}$ : "The style thus of the times and school of thought plus the style determined by individual abilities and personality, thus form style in its broadest sense". The development of the personal style of Ben Marais his involvement in the subject of his study and his characteristic first person reference reflects at once on his warm personality and on his aesthetic appreciation of the beautiful (1932:31) $)^{15}$ : "I read my first sketch in the evening - when the aroma of his first dawn blossoms wakened my heart to new life." Ben Marais' study of Dutch Romanticism certainly influences his writing style and approach to life in general. However, his M.A.-dissertation in Philosophy appears foreign to his style, considering his dissertation on Arthur van Schendel and his later writings.

12 "Die ware Romantikus staan nie buite die realiteit en trag ook nie om in sy kuns die realiteit te ontwyk nie, staan nie buite en los van die reële lewe nie".

13 "Min hartstogtelikheid en min warmte of innigheid. Dit was die breë - wel fyn soms - maar tog byna kleurlose Historiese dokumente - diep persoonlike aksent was daar nie".

14 "Die style dus van die tyd of rigting plus die styl wat op individuele aanleg en persoonlikheid berus, maak dus styl in sy wydste betekenis uit".

15 "Dit was in die aand dat ek my eerste skets gelees het - dat die geur van sy eerste môrebloesem my hart tot nuwe lewe gewek het". 


\subsubsection{M.A. in Philosophy, Stellenbosch, 1935}

The dissertation, Die ontwikkeling van die probleem van die onsterflikheid in die Griekse filosofie ${ }^{16}$, provides a framework within which Ben Marais' philosophical approaches to questions and problems and his historical orientation is illustrated quite clearly. It is thus evident that his studies in philosophy clearly influenced his later work.

The dissertation follows a historical argument, with a first chapter considering the problem of immortality. The next chapters consider, in order, the Homeric era, the early philosophers, the anthropological period, the period of classical Greek Philosophy, and the Hellenistic-Roman philosophers. He then draws a conclusion.

The dissertation closes with a reference to Plotinus on the death of philosophy - intuitive doctrine, which Ben Marais related to the springboard of Christianity (1935:103). It is thus possible to discern how Ben Marais was taught on the periodisation of schools of thought, of which the Christian thinkers formed an important part. It is interesting, though, that Christianity was already flourishing when Plotinus, a contemporary of Origen ( $3^{\text {rd }}$ century CE) was active. Ben Marais argued (1935:103): "Christianity was at the door - the nations were ready for it, with the mysticism of Plotinus Greek Philosophy disappeared from the scene".

Thus, from the historical periodisation of his material, and the positioning of the schools of thought, it is possible to see that Ben Marais' orientation to Greek Philosophy was retrospective, from a Christian point of view. Christian doctrine was thus his hermeneutical key to understanding philosophic concepts.

The bibliography, at the front of the dissertation, contains only 35 titles, but contains a balance between primary and secondary sources. The text is error ridden, and the personal style, writing in first person is well developed. He thus says, "That is why we talk today..."17 (1935:9), using the royal plural in an argumentative mode. The frequent reference to and occurrence of "volk" is quite alarming for a study on immortality.

16 "The development of the problem of immortality in Greek Philosophy".

17 "Daarom praat ons vandag". 
The argument of the dissertation commences with a quotation of Pascal, the source of which he does not indicate (it is definitely through a secondary reference). The quotation serves no other purpose than to elevate the status of the argument through a reference to a well-known name. For that matter, it could have been Plato, Aristotle, Thomas Aquinas or Nietszche. Ben Marais uses the words of Pascal to good effect (1935:1): "The immortality of the soul is an issue that affects us intimately ... what our final purpose should be" ${ }^{\text {"18 }}$. Ben Marais continues, in own pen, to provide an elaboration on this statement with an interesting reference to death. Personally as a child, he had to deal with death under very strenuous conditions, when first his mother, and then his eldest brother died. He writes in his thesis (1935:1): "Death is a sombre reality. It comes to everyone. But whether there is a life after death, is the question that thinkers throughout the centuries of darkness have struggled with" ${ }^{\text {"19 }}$. The pre-Christian era could be depicted as the dark era, and the era of Christianity as the era of light. Though, even then the problem would remain the restriction of perspective: the living can only learn about the conditions of the deceased through the veils of death - assuming that Scripture provides a divinely ordained account of what truly happens after death. The problem of immortality would then be resolved in Christianity - in the faith in life after death (1935:7).

The concept of immortality - depending on faith, Ben Marais argues (1935:2) is to be differentiated from nation to nation (volk) and from century to century - as well as amongst individuals within a nation or time frame. Also, that where there was faith in immortality, there was also denial and disbelief (1935:3). This is an important consideration, that Ben Marais had realised early in his academic development that an argument could be argued from the point of view of both the advocators and oppressors. Thus when a one sided argument was presented, he would invariably have asked for alternative points of view. This is quite evident in his opposition to scriptural justification of Apartheid.

Ben Marais' power of discernment is formulated in his observation that ideas must be distinguished continuously (1935:4). This is especially

18 "Die onsterflikheid van die siel is " $\mathrm{n}$ saak wat ons so intiem raak ... wat ons finale doel moet wees".

19 My translation. 
important in his understanding and application of history - the concept of interrelation - in which the old and the new are related and set apart from each other. He constantly differentiates between earlier concepts and the contemporaneous views (1935:9).

Before entering a detailed discussion on the different philosophers' view points on immortality (1935:25-102), Ben Marais concludes his discussion on the role the mystery religions played in influencing Greek concepts of immortality in Greek thought (1935:24).

Though it might well be possible to critically question Ben Marais' periodisation and prominence given to Christian doctrine, it is significant to see in this dissertation a historic awareness and frame of reference. At this point in his academic career, he did not see himself as a historian. $\mathrm{He}$ had first specialised in Afrikaans, where his historical awareness almost prevailed over his under developed poetic abilities, and here, in his masters dissertation in philosophy, it is more evident, also his search for basic principles according to which he could organise his arguments.

\subsubsection{M.Th. in Theology, Princeton, 1936}

His Masters degree in Theology at Princeton University was completed under the guidance of Samuel Zwemmer. He was highly commended as a student and was well respected by his fellow students.

Unfortunately a copy of the dissertation could not be traced, but it is known that it contains views that were groomed at Stellenbosch that he expanded upon (Viljoen Interview 1986). The fact that the title is very similar (Die Godsidee by die Grieke: probleme van die ontwikkeling in die onsterflikheid van die Griekse Filosofie) ${ }^{20}$, and considering the limited time spent on it, are indicators that it would have contained much of the same material.

\subsubsection{D.Phil. in Philosophy, Stellenbosch, 1946}

Ben Marais completed his D.Phil with the title: Die Christelike broederskapsleer en sy toepassing in die Kerk van die eerste drie eeue, in 1944 at the University of Stellenbosch, under Prof B B Keet's guidance. Interestingly, J D Vorster (an adversary of Ben Marais) completed his D.Th. in

20 The exact English title is unknown, though a possible rendition could be: The idea of God in Greek thought: problems in the development of immortality in Greek Philosophy - the dissertation was most probably written in English. 
Church Law also under Professor B B Keet! Ben Marais' thesis consists of two volumes. Volume One contains sections A and B while section two contains section $\mathrm{C}$ and the bibliography. The thesis is dedicated to his father, "in thankful recognition" "21. He had first enrolled in 1944, with Brummer, professor of Philosophy, as his promoter. Though the doctoral thesis was not written in his youth, it summarises the theological forming of his youth, which was to determine his later thought and pronouncements.

The central question Ben Marais asks in the thesis is: How did the Early Church approach the issues of race and nationalism? The thesis is philosophical and considers the mystery religions, Judaism in the Diaspora, Stoic philosophy, and the background of Christianity. He is looking for insight into the Early Church as an ecumenical community. First he considers the spiritual and cultural milieu in which Christianity developed. $\mathrm{He}$ looks particularly at the general trends prevalent in the Mediterranean world in the centuries prior to the birth of Christ. In the second section he considers the principles of the doctrine of brotherhood and its social implications. In the third section he looks at how the doctrine of brotherhood was applied in the early church.

Ben Marais' periodisation of the early church as covering only the first three centuries is significant. The problems experienced by the church when it became state church and further institutionalised were thus not covered in the thesis, problems which are central and comparative to the predicaments the church found itself in during the $20^{\text {th }}$ century in South Africa. It appears that Ben Marais is doing this deliberately to work with the often idealised early church as reference for his argument. He (1946: iv) sub-divides the period into four sub-periods, which in turn reveals his orientation to conflict: $(30-110 \mathrm{CE})$ the apostolic era; $(110-180 \mathrm{CE})$ the era of the early apologists; (180-250 CE) the era of the great thinkers; (250$313 \mathrm{CE})$, the era of final battle.

Ben Marais wanted to make the doctrine of brotherhood, which underlies and is one of the basic principles in his theology, and which is prevalent in the Early Church, applicable to the current situation in South Africa. The doctrine of brotherhood was determined by the nature of God and the value of humankind. Therefore, the church and Christians had a

21 "Dankbare erkentlikheid". 
social responsibility that should be exercised in specific contexts and situations. He also determined that Christians were in a new relation, a brotherhood. Furthermore, Ben Marais applied the doctrine to race relations in the last chapter of the thesis. Here, he reasoned that because Christianity was universal in nature, and because Christian brotherhood transcends race differences, expression to these facts had to be made in church and society, which also, could not ignore the "concrete situation" nor the "real historical conditions". The thesis was an aid to the question whether there were scriptural grounds for separate churches.

The influence of the doctorate and his reasoning in it is clearly discernible in Two faces of Africa, in which Ben Marais foresees national differences being nullified through the church. Ironically, the NG Kerk contributed towards accentuating nationalistic differences. He delivered a speech at the Faculty of Theology of the University of Stellenbosch on race justification and Scripture (Op die Horizon IX, 1947:66), which was a direct result of his thesis. On a closer reading of the thesis it is apparent that the contemporary situation in South Africa had a far greater influence on his reasoning and organisation of his thoughts than did his study of the Greek philosophers, Scripture and the Early Church.

Alternatively, his awareness of the greater world, of history and different schools of thought and ideologies, would have enabled him to place the narrow ideologically orientated situation in South Africa in perspective. This is apparent where he considers (Marais 1946:21) the variety and strength of the streams that flowed together, resulting in the state of humanity changing, as the organisation of the world changed the character of the nations changed also. In the old world of the Greek civilisation Ben Marais saw the development of the cosmopolitan society growing in accordance to the broadening of horizons, of prospects that improved, of the appreciation of virtues, while the restrictive militarism and patriotism fell into disfavour, interestingly, resulting in one empire, one predominate language and one civilisation. Though the old world was not as uniform as Ben Marais attempts to argue, the influence of Western philosophy on his thinking is quite apparent, where the continuation of civilisation, of the outflow of western civilisation from Greek origin through to Western European civilisation is both natural and uncomplicated. 
Ben Marais was not exposed to other views, and therefore had to develop most of his thoughts in isolation.

\section{CONCLUSION: PRINCIPLES}

What were the principles that governed Ben Marais' thoughts and actions? These principles were grained into his person before he went to university, and each new experience he underwent, or alternative point of view he was confronted with, or action he had to take or was tempted to take were measured against these principles.

The most important factor in Ben Marais' life, his primary principle was faith in God. Other things were secondary.

Thus, to maintain that "Christianity transcends race" as a principle is secondary. This was used as a title of an article Ben Marais prepared for the World Council of Churches in which he maintains that one could make practical arrangements but could not exclude any one on any grounds. Though, it is derived from his primary principle.

It could be maintained that the doctrine of Christian brotherhood was a principle which governed Ben Marais' actions and thoughts on segregation and Apartheid. However, in his doctoral thesis (1946:90) he considers the principles of this doctrine, and uses the words of J H Oldham (1935: 337) to formulate the principle governing his principle of the doctrine of Christian brotherhood: "The ultimate question which determines the character of man or of a civilization is the kind of God that a man worships or that men collectively worship". It is thus quite understandable why Ben Marais' thesis in Philosophy was orientated towards Christianity, and why he did not find it necessary to qualify himself. Ben Marais' principles rest in his 'concept of God' as in the Old and New Testament. Thus ethics were related to his concept of God (Marais 1946:83). He was an evangelical who was philosophically schooled.

Two further principles need to be mentioned here, since at once they indicate the influences on his thought, and how they determined his actions. The first concerns the unity of mankind and is a culmination of Acts 17:26, and Berkhoff's Reformed Dogmatics as read in Ben Marais' doctoral thesis (1946:114): "The human race is ... a unity. Not only do we share the same human nature, but through Adam there is also a genetic and genealogical unity between all people". The second principle is an understanding of the unity of humanity in sin, and in the brotherhood of 
salvation (Marais 1946:119), and this principle is governed by God's relation to mankind. To formulate his ideas, Ben Marais uses the words of Emil Brunner (Marais 1946:120): "Fellowship with God creates fellowship with man, and genuine human fellowship is only possible as it is based upon fellowship with God. Thus human fellowship rests upon the same foundation as fellowship between man and God".

While Ben Marais could not accept statements he did not agree with, and therefore could never have become a political activist, it is apparent that he had a network of principles that made it impossible for him to suppress his conscience at the synods of the Nederduits Hervormde of Gereformeerde Kerk in the 1940s.

\section{Consulted Literature}

1931. Die kerksaak tussen Prof J du Plessis en die Ned. Geref. Kerk in Suid Afrika. 'n Woordelike verslag van die verrigtinge, met die uitspraak, in die Hooggeregshof, Kaapstad, November - Desember 1931. Kaapstad: Nasionale Pers.

1935. Handelinge van die Raad van Kerke.

1944. Agenda van die 20ste Sinode van die Ned. Herv. of Geref. Kerk.

1944. Handelinge van die Sinode van die Ned. Herv. of Geref. Kerk.

1944. Verslag van die Sinodale Kommissie van die Ned. Herv. of Geref. Kerk.

1947. Handelinge van die Raad van Kerke.

1948. Wette en Bepalinge vir die Regering van die Nederduitse Hervormde of Gereformeerde Kerk van Suid Afrika.

1948. Handelinge van die Sinode van die Nederduitse Hervormde of Gereformeerde Kerk van Suid Afrika.

1997. Die Verhaal van die Ned Geref Kerk se Reis met Apartheid: 1960-1994: 'n Getuienis en ' $n$ Belydenis. Opgestel in opdrag van die Algemene Sinodale Kommissie van die Ned Geref Kerk.

Aucamp, B 2002. An historian from Steynsburg, Interview 17 September 2002.

Berkhoff, L 1937. Reformed Dogmatics. Grand Rapids: Eerdmans.

Botha, C J 1979. "Ben Marais se Stryd in die Sinodes teen die 'Bybelse Fundering van Apartheid", in A.C. Viljoen (red), Ekumene onder die Suiderkruis. Pretoria: Universiteit van Suid Afrika, 15-34.

Brown, E 1992. "Die kerklike en akademiese bydrae van Prof Ben (Barend) J (Jacobus) Marais", in Ned Geref Teologiese Tydskrif 33(4), 482-494.

Du Plessis, C C 2002. Grandfather (Botha) was the brother of Ben Marais' mother; Mara Marais lived with Du Plessis' grandparents, 12 September 2002. 
Du Plessis, J 2002. Mother, Mara, was youngest sister of Ben Marais, 4 October 2002.

Gerdener, G B A 1943. Die Boodskap van 'n Man: Lewenskets van Prof. J Du Plessis. Stellenbosch: CSV-Boekhandel.

Hattingh, A 2002. Mother was sister of Ben Marais' mother. Melvina Marais lived with Hattingh's mother (Botha), 17 September 2002.

Hofmeyr, J W 1985. "Kerkgeskiedenis, Die Koningin van die Teologiese Wetenskappe", Deel 1, in Theologia Evangelica 18(3), 32-41.

-, 1988. "Kerkgeskiedenis, Die Koningin van die Teologiese Wetenskappe", Deel 2, in Theologia Evangelica 21(1).

Hofmeyr, J W, Lombaard, C J S \& Maritz, P J (eds) 2001. 1948 Plus 50 Years: Theology, Apartheid and Church: Past, Present and Future. Pretoria: IMER Publishers.

Hofmeyr, J W \& Pillay, G J (eds) 1994. A History of Christianity in South Africa. Volume 1. Pretoria: Haum Tertiary.

Keet, B B 1956. Whither South Africa? Stellenbosch: University Publishers.

Krause, O 1973. Dr Ben Kyk Terug: en Nou Sê Almal So, in Rapport 4 March 1973:15.

Marais, A 2002. Ben Marais' daughter, 17 December 2002.

Marais, B J 1932. Stylvernuwing by Arthur van Schendel. Unpublished MADissertation, University of Stellenbosch.

-, 1935. Probleme van die ontwikkeling van die onsterflikheid in die Griekse filosofie. Unpublished MA-dissertation, University of Stellenbosch.

-, 1940. "Ons Sendingbeleid", in Die Kerkbode, 15 May 1940.

-, 1946. Die Christelike Broederskapsleer en sy Toepassing in die Kerk van die Eerste Drie Eeue. Unpublished D.Phil-Thesis, University of Stellenbosch.

-, 1947. "'n Kritiese Beoordeling van die Standpunt van Ons Kerk Insake Rasseverhoudings met die oog op die Gebeure Oorsee", in Op die Horison, IX, 2 June 1947.

-, 1952. Colour: unsolved problem of the West. Cape Town: Timmins.

-, 1954. "Address to World Council of Churches", Evanston: Unpublished Pretoria NG Kerk Archives.

-, 1958. Rondom die Eenheid van die Kerk van Christus en die Ekumeniese Beweging. Cape Town: NG Kerk-Uitgewers.

-, 1960. "Die Kerk in die Huidige Wêreld", in A S Geyser (et al). Vertraagde Aksie. ' $n$ Ekumeniese Getuienis uit die Afrikaanssprekende Kerk. Pretoria: Die Outeurs. 
-, 1961. "Op My Wagpos: Vurige Nasionalisme by Alle Afrika State", in Werda, 1 August 1961.

-, 1962. "Eine Stimme aus dem Südliche Afrika", in C Berg (red), Stimme aus der Ökumene, FS for WA Visser't Hooft. Amsterdam.

-, 1964a. "Besware Teen en Probleme om die Ekumene", in A J van Wijk (red), Die Ekumene: 'n Besinning in Interkerklike Verhoudinge. Stellenbosch: Kosma.

-, 1964b. The two faces of Africa. Pietermaritzburg: Shuter \& Shooter.

-, 1964c. Wit Huise van Herinneringe: Oordenkinge vir een-en-dertig dae. Pretoria: NG Kerk-Uitgewers.

-, 1972. "Real Brotherhood in South Africa" (Report of SPROCAS: The Church and Apartheid), in Pro Veritate, 15 February 1972.

-, 1975(?). "Autobiographical Notes". Loose Manuscript. Pretoria: NG Kerk Archive.

-, 1976. "My Eerste Sinode", in Die Voorligter, 39(2), 1 January 1976.

-, 1985. Letter to the Editor, "Kerke se Besluit Laat 'n Mens se Hart Gloei", in Die Burger, 29 January 1985.

Marais, P A 2002. Mother, Johanna, was Ben Marais' eldest sister, 20 September 2002.

Marais, S 2000. Ben Marais' wife. Various occasions.

Maritz, P J 2003. Ben Marais (1909-1999): The influences on, and heritage of a South African prophet during two periods of transformation. Ph-D-thesis, University of Pretoria.

Meiring, P G J 1979. “"No Regrets', - 'n Vraaggesprek met professor Ben Marais oor hoogtepunte in sy lewe", in A C Viljoen (ed), Ekumene onder die Suiderkruis. Pretoria: Universiteit van Suid Afrika, 78-91.

Shillito, E 1933. Nationalism: Man's Other Religion. Chicago: Willet Clark \& Company.

Van der Watt, P B 1987. Die Nederduitse Gereformeerde Kerk: 1905-1975. (Deel IV). Pretoria: NG Kerkboekhandel.

Viljoen, A 1986. In gesprek met Oom Ben. Pretoria: University of South Africa. 